\title{
Penerapan Model Pembelajaran Problem Solving Sebagai Upaya Meningkatkan Prestasi Belajar Matematika
}

\author{
I Ketut Manik* \\ Sekolah Dasar Negeri 1 Tulamben, Karangasem, Indonesia
}

\author{
A R T I C L E I N F O \\ Article history: \\ Received 12 February \\ 2020 \\ Received in revised form \\ 19 March 2020 \\ Accepted 25 April 2020 \\ Available online 27 May \\ 2020 \\ Kata Kunci: \\ Pembelajaran Problem \\ Solving, Prestasi Belajar \\ Keywords: \\ Problem Solving Learning, \\ Learning Achievement
}

\begin{abstract}
A B S T R A K
Penelitian ini dilaksanakan di Satdik SD Negeri 1 Tulamben di Kelas VI sebanyak 37 orang yang kemampuan siswanya untuk materi matematika cukup rendah. Tujuan penulisan penelitian tindakan kelas ini adalah untuk mengetahui apakah model pembelajaran Problem Solving dapat meningkatkan prestasi belajar matematika siswa. Metode pengumpulan datanya adalah tes prestasi belajar. Metode analisis datanya adalah deskriptif. Hasil yang diperoleh dari penelitian ini adalah prestasi belajar matematika siswa dapat meningkat. Ini terbukti dari hasil yang diperoleh pada Siklus I rata-ratanya 64,595, dengan ketuntasan $64,86 \%$. Sedangkan rat-rata siklus II mencapai 72,568 , dengan presentase ketuntasan 97,30\%. Dari Siklus I ke Siklus II terjadi kenaikan rata-rata prestasi belajar matematika sebesar 7,973, sedangkan presentase ketuntasan belajarnya naik $32.44 \%$. Kesimpulan yang diperoleh dari penelitian ini adalah model pembelajaran Problem Solving dapat meningkatkan prestasi belajar.
\end{abstract}

\section{A B S T R A C T}

This research was conducted at Satdik SD Negeri 1 Tulamben in VI grade with 37 students whose student abilities for mathematics material were quite low. The purpose of writing this class action research is to find out whether the Problem Solving learning model can improve student mathematics learning achievement. The data collection method is a learning achievement test. The data analysis method is descriptive. The results from this study are the mathematics learning achievement of students can increase. This is evident from the results in Cycle I was 64.595, with $64.86 \%$ completeness. While the average cycle II was 72.568 , with a percentage of completeness $97.30 \%$. From Cycle I to Cycle II there was an increase in mathematics learning achievement was 7.973 , while the percentage of mastery learning increased by $32.44 \%$. The conclusion from this study is the Problem Solving learning model can improve learning achievement. 


\section{Pendahuluan}

Peran mata pelajaran matematika adalah untuk pengembangan intelektual, sosial dan emosional siswa serta berperan sebagai kunci penentu menuju keberhasilan dalam mempelajari suatu bidang tertentu. Fungsi mata pelajaran matematika adalah sebagai suatu bidang kajian untuk mempersiapkan siswa mampu merefleksikan pengalamannya sendiri dan pengalaman orang lain, mengungkapkan gagasan-gagasan dan perasaan serta memahami beragam nuansa makna, sedang kegunaannya adalah untuk membantu siswa mengenal dirinya, budayanya, budaya orang lain, mengemukakan gagasan dan perasaan, berpartisipasi dalam masyarakat, membuat keputusan yang bertanggung jawab pada tingkat pribadi, sosial, menemukan serta menggunakan kemampuan analitic dan imajinatif yang ada dalam dirinya. Disamping mengetahui peran, fungsi dan kegunaan mata pelajaran, sebagai seorang guru juga diperlukan untuk mampu menerapkan beberapa metode ajar sehingga paradigma pengajaran dapat dirubah menjadi paradigma pembelajaran sebagai tuntutan peraturan yang disampaikan pemerintah (Permen No. 41 tahun 2007 tentang Standar Proses).

Kelemahan-kelemahan yang terjadi selama proses pembelajaran yang dilakukan selama ini yang menyebabkan rendahnya prestasi belajar matematika siswa tentu tidak sepenuhnya disebabkan oleh faktor luar seperti kesibukan guru, keadaan rumah tangga, lingkungan dan lain-lain. Kelemahankelemahan yang ada tentu banyak pula dipengaruhi oleh faktor dari dalam guru itu sendiri seperti kemauan menyiapkan bahan yang lebih baik, termasuk kemauan guru itu sendiri untuk menerapkan metode-metode ajar yang telah didapat di bangku kuliah. Selain itu guru juga kurang mampu untuk dapat mengembangkan keterampilan mengajar yang dapat menarik perhatian siswa dan merangsang siswa untuk belajar. Keterampilan yang mesti dikuasai guru dalam melaksanakan pembelajaran ada 7, yaitu: 1) keterampilan bertanya, 2) keterampilan memberi penguatan, 3) keterampilan mengadakan variasi, 4) keterampilan menjelaskan, 5) keterampilan membuka dan menutup pelajaran, 6) keterampilan membimbing diskusi, 7) keterampilan mengelola kelas. Keterampilan-keterampilan ini berhubung dengan kemampuan guru untuk menguasai dasar-dasar pengetahuan yang berhubungan dengan persiapan dan pelaksanaan proses pembelajaran yang akan memberikan dukungan terhadap cara berpikir siswa yang kreatif dan imajinatif. Hal inilah yang menunjukkan profesionalisme guru (I G. A. K. Wardani dan Siti Julaeha, Modul IDIK 4307: 1-30).

Penggunaan model-model pembelajaran juga merupakan hal yang sangat penting dalam upaya memajukan suatu bidang tertentu. Model sangat berkaitan dengan teori. Model merupakan suatu analog konseptual yang digunakan untuk menyarankan bagaimana meneruskan penelitian empiris sebaiknya tentang suatu masalah. Jadi model merupakan suatu struktur konseptual yang telah berhasil dikembangkan dalam suatu bidang dan sekarang diterapkan, terutama untuk membimbing penelitian dan berpikir dalam bidang lain, biasanya dalam bidang yang belum begitu berkembang (Mark 1976 dalam Ratna Wilis Dahar, 1989: 5).

Cuplikan di atas menunjukkan betapa pentingnya model untuk diterapkan dalam mencapai suatu keberhasilan, begitu pula terhadap kegunaan model-model pembelajaran. Sebelum ada model, dikembangkan terlebih dahulu teori yang mendasari model tersebut, sehingga boleh dikatakan bahwa teori lebih luas daripada model. Model-model, baik model fisika, model-model komputer, model-model matematika, semua mempunyai sifat "jika - maka", dan model-model ini terkait sekali pada teori (Shelbeeker, 1974 dalam Ratna Wilis Dahar, 1989: 5).

Dari semua uraian di atas dapat diketahui hal-hal yang perlu dalam upaya meningkatkan aktivitas dan prestasi belajar siswa seperti penguasaan metode-metode ajar; penguasaan model-model pembelajaran; penguasaan teori-teori belajar; penguasaan teknik-teknik tertentu; penguasaan peran, fungsi serta kegunaan mata pelajaran. Apabila betul-betul guru menguasai dan mengerti tentang hal-hal tersebut dapat diyakini bahwa prestasi belajar peserta didik pada mata pelajaran matematika tidak akan rendah. Namun kenyataannya prestasi belajar siswa kelas VI di semester 1 tahun pelajaran 2019/2020 prestasi belajar baru mencapai rata-rata 55,95 dengan ketuntasan 37,84\%.

Melihat kesenjangan antara harapan-harapan yang telah disampaikan dengan kenyataan lapangan sangat jauh berbeda, dalam upaya memperbaiki mutu pendidikan utamanya pada mata pelajaran matematika, sangat perlu kiranya dilakukan perbaikan cara pembelajaran. Salah satunya adalah perbaikan pembelajaran dengan menggunakan model pembelajaran Problem Solving.

Model Problem Solving lebih banyak menekankan pada kemampuan berpikir tingkat tinggi. Untuk bisa melakukan ini maka diperlukan kecerdasan yang baik. Dalam hubungan matematika, karakteristik kecerdasan matematika yang dikemukakan oleh Judith Jewell (dialih bahasakan oleh Alexander Sindoro, 2003: 19) adalah pandai memecahkan teka-teki angka dan soal abstrak, memahami statistik yang diterbitkan dalam berita dan tahu kalau bisa menyesatkan, senang mengetahui cara kerja berbagai peralatan, dan tahu cara membetulkan peralatan yang rusak, sering membuat daftar tugas yang diberi 
nomor. Dalam hubungan dengan tingkat berpikir tinggi, penulis coba hubungkan dengan pemahaman konsep dan berpikir formal. Pemahaman konsep seperti dikemukakan oleh Gagne (dalam Ratna Wilis Dahar, 1989: 85-86) yang merupakan prosedur bentuk belajar pemecahan masalah adalah menggabungkan aturan-aturan untuk mencapai suatu pemecahan yang menghasilkan sesuatu aturan dengan tingkat lebih tinggi. Apabila dihubungkan dengan tingkat berpikir formal, maka para siswa yang mampu berpikir tingkat tinggi akan mampu melakukan pengaturan sendiri dan keseimbangan.

Cholis (2002) dalam Dyah Retno Kusuma Wardani (2011: 58) menyebutkan ada beberapa hal yang perlu diperhatikan dalam pembelajaran pemecahan masalah yakni: 1) menentukan permasalahan yang akan disajikan disesuikan dengan materi, 2) masalah yang disajikan harus mampu mendorong siswa berpikir dari berbagai sudut pandang yang berbeda, 3) masalah harus disesuaikan dengan dengan tingkat kemampuan siswa, 4) masalah harus jelas, 5) masalah dikaitkan dengan dunia nyata dan cukup menarik siswa. M. Nur (2007) mengatakan bahwa ciri kelas yang melaksanakan pembelajaran adalah: 1) siswa secara aktif terlibat dalam pembelajaran, 2) siswa belajar dari temannya melalui kerja kelompok, diskusi, saling mengkoreksi, 3) pembelajaran menekankan pada masalah bersifat terbuka, 4) prilaku siswa dibangun atas kesadaran diri dan hadiah untuk prilaku baik adalah kepuasan diri, 5) siswa menggunakan kemampuan berpikir kritis dan kreatif terlibat penuh dan ikut bertanggung jawab dalam mengayakan terjadinya proses pembelajaran yang efektif, 6) penghargaan terhadap pengakuan siswa sangat diharapkan.

Model pembelajaran Problem Solving atau model pemecahan masalah pengupayakan agar siswa dapat melakukan pembelajaran dengan tidak menghafal, tetapi melakukan pembelajaran dengan mengupayakan agar mereka bisa berpikir logis, rasional, kritis, cermat, jujur dan efektif. Disamping itu mampu memecahkan masalah yang sedang dihadapi dengan memahami masalah tersebut, membuat perencanaan pemecahannya, menyelesaikan masalah tersebut dengan mengecek kembali langkahlangkah yang bisa diupayakan untuk itu. Siswa mesti diupayakan untuk mampu menggunakan proses berpikir yang lebih jauh dan lebih dalam, terlibat lebih aktif seperti berdiskusi, berprestasi, saling mengoreksi serta pemberian hadiah oleh guru bagi yang berprestasi. Guru mesti berupaya pada model pembelajaran ini dengan mengupayakan proses pemecahan masalah melalui kelompok-kelompok kecil yang akan memberi kesempatan atau peluang bagi para siswa untuk lebih banyak bertukar pikiran, bertukar pendapat untuk pencapaian keberhasilan yang lebih baik.

Berdasarkan uraian ini jelas bahwa model pembelajaran Problem Solving menuntut kemampuan siswa untuk giat mempelajari apa yang disampaikan guru, mampu menampilkan dirinya di depan siswasiswa yang lain. Dipihak lain, untuk dapat menyelesaikan tuntutan tersebut, inovasi yang dilakukan guru akan sangat menentukan. Inovasi tersebut berupa tuntunan-tuntunan, pemberian fasilitas-fasilitas, motivasi-motivasi, interpretasi serta kemampuan implementasi yang tinggi. Langkah-langkah inilah yang dapat digunakan memecahkan masalah penelitian.

Tujuan penelitian ini adalah untuk peningkatan prestasi belajar matematika siswa kelas VI Satdik SD Negeri 1 Tulamben semester 1 tahun pelajaran 2019/2020 setelah diterapkan model pembelajaran Problem Solving.

\section{Metode}

Penelitian yang dilakukan termasuk penelitian tindakan. Oleh karenanya, rancangan yang khusus untuk sebuah penelitian tindakan sangat diperlukan. Penelitian tindakan didasarkan pada filosofi bahwa setiap manusia tidak suka atas hal-hal yang statis, tetapi selalu menginginkan sesuatu yang lebih baik. Peningkatan diri untuk hal yang lebih baik ini dilakukan terus menerus sampai tujuan tercapai (Suharsimi Arikunto, Suhardjono, Supardi, 2007: 74).

Dalam melaksanakan penelitian, rancangan merupakan hal yang sangat penting untuk disampaikan. Tanpa rancangan, bisa saja alur penelitian akan ngawur dalam pelaksanaannya. Untuk penelitian ini penulis memilih rancangan penelitian tindakan yang disampaikan oleh (Arikunto, Suharsimi, 2007) seperti terlihat pada gambar berikut. 


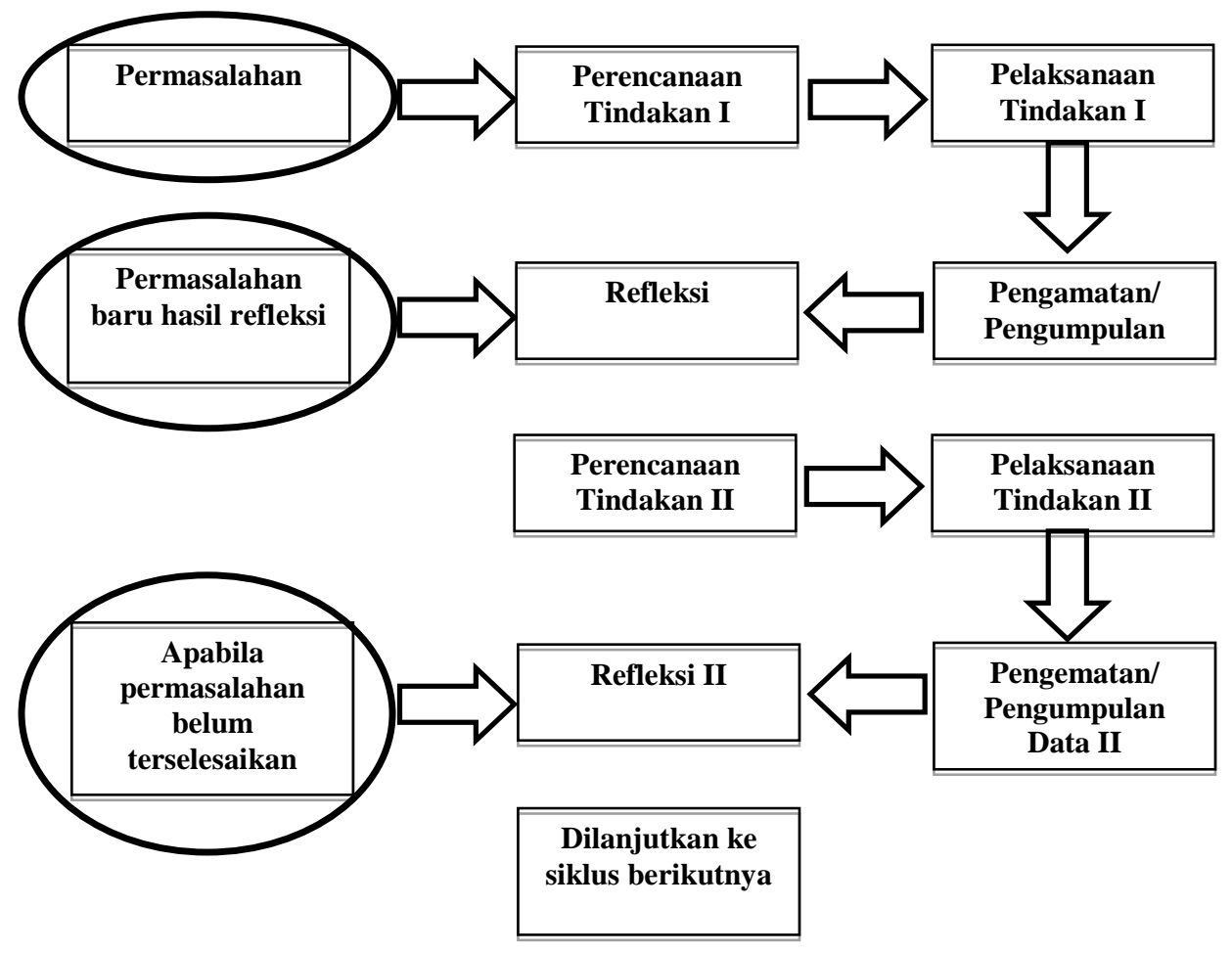

Gambar 1. Alur Penelitian Tindakan Kelas

(Suharsimi Arikunto, Suhardjono, Supardi, 2007: 74)

Subjek penelitian ini adalah semua siswa kelas VI Satdik SD Negeri 1 Tulamben yang berjumlah 37 orang terdiri dari 15 laki-laki dan 22 perempuan. Sedangkan yang menjadi objek penelitian ini adalah peningkatan prestasi belajar siswa kelas VI Satdik SD Negeri 1 Tulamben setelah diterapkan model Problem Solving dalam proses pembelajaran. Untuk mengumpulkan data penelitian ini mengunakan tes prestasi belajar. Metode yang digunakan untuk menganalisis data hasil penelitian ini adalah metode deskriptif. Untuk data kuantitatif dianalisis dengan mencari mean, median, modus, membuat interval kelas dan melakukan penyajian dalam bentuk tabel dan grafik. Indikator keberhasilan penelitian yang diusulkan dalam penelitian ini pada mencapai nilai rata-rata 70 atau lebih dengan ketuntasan belajar klasikal 80\%

\section{Hasil dan pembahasan}

Pada bagian ini, akan dipaparkan data yang diperoleh dari penelitian tindakan ini secara rinci berdasarkan penelitian yang dilakukan di Satdik SD Negeri 1 Tulamben. Sebelum menyampaikan hasilhasil penelitian ada baiknya dilihat dahulu pendapat para ahli pendidikan berikut: dalam menyampaikan hasil penelitian dan pembahasan, perlu menyajikan uraian masing-masing siklus dengan data lengkap mulai dari perencanaan, pelaksanaan, pengamatan dan refleksi yang berisi penjelasan tentang aspek keberhasilan dan kelemahan yang terjadi. Perlu ditambahkan hal yang mendasar, yaitu hasil pembahasan (kemajuan) pada diri siswa, lingkungan, guru, motivasi dan aktivits belajar, situasi kelas dan hasil belajar, kemukakan grafik dan tabel hasil analisis data yang menunjukkan perubahan yang terjadi disertai pembahasan secara sistimatis dan jelas (Suharsimi Arikunto, Suhardjono, Supardi, 2006: 83). Melihat paparan ini jelaslah apa yang harus dilihat dalam Bab ini yaitu menulis lengkap mulai dari apa yang dibuat sesuai perencanaan, hasilnya apa, bagaimana pelaksanaanya, apa hasil yang dicapai, sampai pada refleksi berikutnya semua hasilnya. Oleh karenanya pembicaraan pada bagian ini dimulai dengan apa yang dilakukan dari bagian perencanaan.

\section{Siklus I}

Hasil yang didapat dari kegiatan perencanaan meliputi: 1) Peneliti membuat Rencana Pelaksanaan Pembelajaran (RPP) yang akan dilaksanakan dengan Model Pembelajaran Problem Solving. Berdasar hasil awal kemampuan belum sesuai harapan,dimana nilai peserta didik yang rendah di kelas pada semester I 
tahun pelajaran 2019/2020 yang baru mencapai 55,95 menuntut peneliti giat berkonsultasi dengan teman- teman guru merencanakan model yang paling tepat untuk menyelesaikan masalah yang ada, menentukan waktu pelaksanaan pembelajaran, menyusun format observasi, merencanakan bahan-bahan pendukung, merancang sekenario pembelajaran yang akan digunakan untuk menyelesaikan masalah. 2) Menentukan waktu pelaksanaan, yang menyangkut hari, tanggal, sesuai dengan jadwal penelitian yaitu pada minggu ke dua, tiga dan empat bulan Oktober. 3) Meminta kepada teman-teman guru bidang studi sejenis dan kepala sekolah sebagai mitra kesejawatan dalam pelaksanaan RPP yang sudah direncanakan. Hasilnya adalah kesiapan teman-teman guru untuk ikut melaksanakan supervisi kunjungan kelas. 5) Menentukan yang menjadi prinsip supervisi teknik kunjungan kelas. Hasilnya adalah format-format perencanaan teknik kunjungan kelas untuk penilaian guru. 6) Sebelum masuk kelas, peneliti meminta guru untuk membawa lembar penilaian yang berisikan tentang penilaian proses pembelajaran. Berdasar format yang sudah dibawa guru, peneliti melakukan pembelajaran sesuai rencana pelaksanaan pembelajaran yang telah dibuat.

Hal-hal yang perlu diperhatikan dalam melakukan supervisi kelas adalah: 1) Supervisor harus sudah mantap dan mengetahui metode pembelajaran yang menggunakan Problem Solving dan kehadirannya di kelas bukan mencari kesalahan, tetapi untuk kepentingan bersama yaitu memperbaiki pembelajaran. 2) Supervisor telah diberitahu untuk lebih memahami tentang prinsip-prinsip supervisi sehingga tidak lagi cenderung instruktif dan lebih bersahabat dengan prinsip kesejawatan. 3) Dalam pelaksanaan supervisi, supervisor diharapkan menunjukkan rasa kesejawatan yang akrab. 4) Guru yang disupervisi diharap tidak selalu memperhatikan supervisor, tetapi tetap berkonsentrasi pada pelaksanaan pembelajaran. 5) Peneliti memberikan penjelasan pada siswa bahwa kehadiran supervisor ke kelas bukan untuk mencari kesalahan atau kelemahan guru dalam pembelajaran, tapi untuk meningkatkan kemampuan menguasai ilmu. 6) Memperbanyak jumlah/frekuensi kunjungan kelas dalam siklus berikutnya sehingga kedekatan supervisor dengan guru dan siswa akan terjalin dengan baik. 7) Merencanakan bahan pelajaran dan merumuskan tujuan. Menentukan bahan pelajaran, dengan cara menyesuaikan dengan silabus yang berlaku dan penjabarannya dengan cukup baik. 8) Memilih dan mengorganisaasikan materi, media, dan sumber belajar. Pada siklus pertama ini, peneliti mengorganisasikan materi pembelajaran dengan baik. Urutan penyampaiannya dari yang mudah ke yang sulit, cakupan materi cukup bermakna bagi siswa, menentukan alat bantu mengajar. Sedangkan dalam penentuan sumber belajar sudah disesuaikan dengan tujuan, materi pembelajaran dan tingkat perkembangan peserta didik. 9) Merancang skenario pembelajaran. Skenario pembelajaran menentukan permasalahan yang akan disajikan sesuai dengan materi dan tingkat perkembangan siswa, diupayakan bervariasi agar siswa dapat melakukan berpikir tingkat tinggi. Susunan dan langkah-langkah pembelajaran sudah disesuaikan dengan tujuan, materi, tingkat perkembangan siswa, waktu yang tersedia, sistematiknya adalah menaruh siswa dalam posisi sentral, mengikuti perubahan strategi pendidikan dari pengajaran ke pembelajaran sesuai Permen Diknas No. 41 Tahun 2007 dengan cara mengaitkan masalah dengan dunia nyata dan yang menarik minat siswa.

Pelaksanan tindakan dilkasakan dengan beberapa langkah yaitu 1. Mengelola kelas dengan persiapan yang matang, mengajar materi dengan benar sesuai perencanaan di RPP. 2. Alat Penilaian. Pembahasan dan jenis penilaian, terlampir di RPP berikut format penilaian, memulai dengan pembukaan, pembelajaran inti, pembelajaran penutup dan dilanjutkan dengan penilaian. 3 . Dari diskusi dengan guru, terungkap bahwa: 1) Pembelajaran yang dilakukan belum maksimal, karena peneliti baru pertamakali mencoba metode ini. 2) Siswa-siswa memang belum aktif menerima pelajaran dan memberi tanggapan, ini sesuai dengan tujuan metode Problem Solving. 3) Peneliti mengusulkan agar guru yang mengamati mau kembali dan bersedia mengamati kembali pada kesempatan di siklus II. 4) Untuk sementara, peneliti belum yakin bahwa pelaksanaan supervisi kunjungan kelas akan meningkatkan aktivitas dan prestasi belajar siswa, tetapi menurut pengamat, cara yang dilakukan peneliti cukup mampu mendorong meningkatkan kreativitas dan prestasi belajar. 5) Penyampaian pengamat pada peneliti dapat disampaikan sebagai berikut: Pengelolaan ruangan, waktu, dan fasilitas belajar. Dalam mengelola ruang kelas, waktu serta fasilitas belajar, dapat dipaparkan sebagai berikut: (1) Peneliti menyediakan alat bantu/media pembelajaran. (2) Peneliti kurang memperhatikan kebersihan papan tulis, kebersihan seragam siswa, dalam hal lain yang berguna untuk menumbuhkan motivasi belajar dan disiplin siswa. (3) Peneliti belum begitu baik dalam waktu. Memulai pelajaran tidak tepat waktu akibat hal-hal tertentu. 6) Penggunaan strategi pembelajaran. (1) Jenis kegiatan sesuai dengan tujuan serta lingkungan siswa. Namun, guru kurang memperhatikan kebutuhan siswa, guru masih menerapkan gaya pembelajaran tradisional. Guru juga kurang memperhatikan disiplin siswa. Banyak siswa yang tidak memperhatikan penjelasan guru. (2) Guru sama sekali tidak menggunakan alat bantu pelajaran, walaupun sekolah telah menyediakannya. (3) Dalam menjelaskan pelajaran, guru kurang memperhatikan keterkaitan materi yang satu dengan materi yang lain. Guru tidak memberikan kesimpulan dan tindak lanjut pada akhir 
pelajaran. (4) Kelebihannya, guru telah menggunakan cara pembelajaran yang baru yaitu Problem Solving. 7) Pengelolaan interaksi kelas. (1) Penjelasan guru cukup dimengerti oleh siswa. Hal ini bisa dilihat dari respon siswa. Jika ada siswa yang belum mengerti, guru berusaha menjelaskan ulang. (2) Dalam bertanya, guru menggunakan kata atau tindakan yang mengurangi keberanian siswa untuk bertanya atau menjawab pertanyaan guru. Guru mengabaikan partisipasi aktif siswa. (3) Dalam menyajikan pelajaran, guru menggunakan komunikasi lisan, tulisan, isyarat, token atau gerakan badan. Pembicaraan guru cukup lancar dan dimengerti siswa, namun gerakan badan atau tangan guru kurang menunjukkan keantusiasan dalam mendorong siswa untuk berpartisipasi aktif. (4) Guru tidak membantu siswa dalam mengingat kembali pengalaman atau pengetahuan yang telah diperoleh siswa dan kurang memberikan peluang kepada siswa yang pasif untuk berpartisipasi. Guru tidak memberi pertanyaan yang menggali reaksi siswa. Cara guru merespon siswa yang berpartisipasi aktif masik kurang baik. (5) Dalam mengakhiri pelajaran, guru kurang mengupayakan kesimpulan yang lengkap. Guru juga kurang melibatkan siswa dalam membuat kesimpulan. Dengan demikian, pembelajaran kurang bermakna bagi siswa. 8) Sikap guru. (1) Dalam kegiatan pembelajaran, kadang-kadang guru kurang bersikap ramah. Guru kurang menunjukkan sikap bersahabat dengan siswa. Dalam menegur siswa yang berbuat salah, guru menggunakan kata yang kurang sopan. Jika ada pendapat siswa yang kurang sesuai dengan pendapat guru, guru langsung menepis begitu saja. (2) Guru sangat bergairah dalam mengajar. Hal itu terlihat dari ekspresi wajah dan pandangan matanya. Tetapi, suara monotun, isyarat tangan dan gerakan tubuh kurang beraturan. (3) Dalam membantu siswa yang menghadapi kesulitan, bantuan guru kurang maksimal. Guru juga tidak mendorong siswa untuk memecahkan masalah sendiri. (4) Guru tidak memperhatikan perbedaan individual siswa. Guru tidak memberi perhatian khusus kepada siswa yang memiliki kelainan, misalnya yang suka usil, pembohong yang pura-pura ikut bekerjasama, tapi dia ngomong lain-lain dari pelajaran. Guru juga tidak memberikan penghargaan kepada siswa yang memiliki kelebihan. Guru tidak membina kerjasama diantara siswa. 9) Pelaksanaan penilaian. Guru mengadakan apersepsi penilaian awal sehingga guru mengetahui kesiapan siswa terhadap materi pelajaran yang akan diajarkan. Penilaian juga dilakukan dalam proses pembelajaran. 10) Kesan umum dalam proses. (1) Penggunaan Bahasa Indonesia sebagai bahasa pengantar cukup jelas, tetapi kurang baku karena bercampur dengan bahasa daerah. Demikian juga Tata Bahasa Indonesianya kurang baik. (2) Penampilan guru dilihat dari perkataan, rambut dan perlengkapan yang lain cukup rapi. Suara cukup jelas tetapi kurang bervariasi. Posisi guru juga kurang ada variasi.

Observasi dilakukan dengan menilai perkembangan anak secara berkelanjutan dengan memperhatikan kemampuan mereka. Hasil penilaian disajikan berikut ini:

Tabel 1. Prestasi Belajar Matematika Siswa Kelas VI Semester I Tahun Pelajaran 2019/2020 Siklus I

\begin{tabular}{cc}
\hline Kreteria penilain & NILAI \\
\hline Jumlah & 2390 \\
\hline Rata-rata & 64.595 \\
\hline Nilai Tertinggi & 90 \\
\hline Nilai Terendah & 50 \\
\hline Modus & 50 \\
\hline Median & 60 \\
\hline KKM & 60 \\
\hline Jumlah siswa Tuntas & $24(64.86 \%)$ \\
\hline Jumlah Tidak Tuntas & $13(35.14 \%)$ \\
\hline
\end{tabular}

Dari Tabel di atas dapat dikatakan bahwa dari 37 siswa yang mengikuti pembelajaran pada siklus I masih ada $13(35,14 \%)$ siswa yang belum tuntas dan siswa yang tuntas $24(64,86 \%)$. Dengan nilai ratarata 64,595 , dimana nilai rata-rata ini meningkat dari pra siklus ini pertanda ada sedikit perbaikan hasil belajar dari siswa tapi dilihat dari nilai mudusnya masih ada beberapa anak yang ada dibawah KKM. Secara lebih rinci dapat ditunukkan pada gambar 01. 


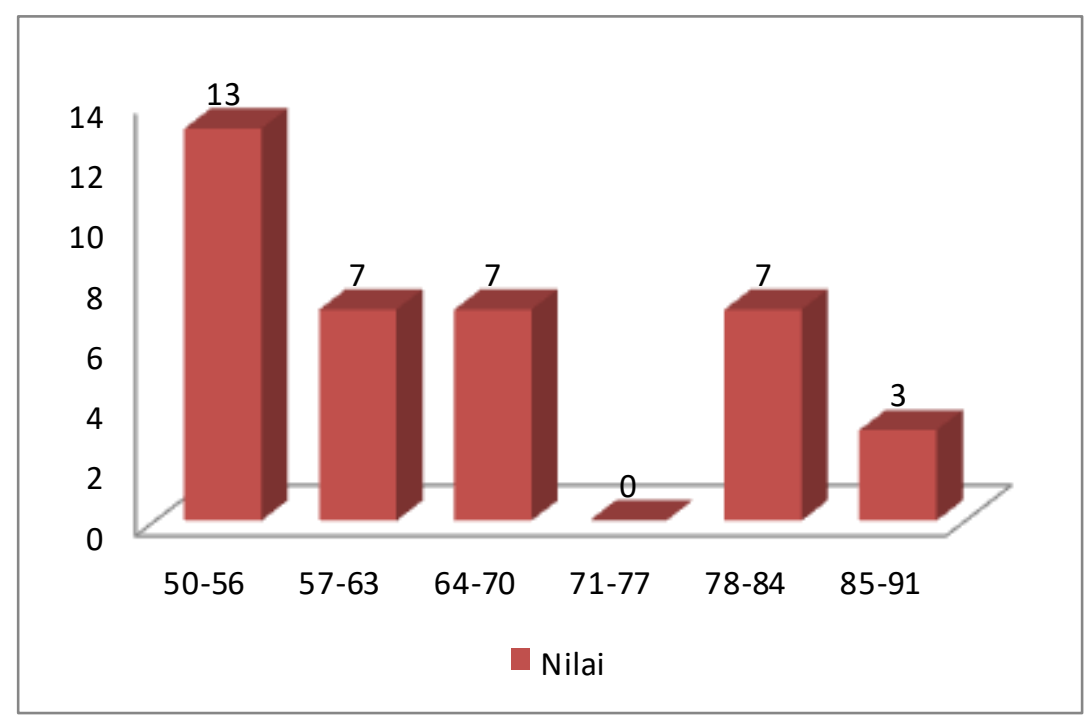

Gambar 2. Histogram Prestasi Belajar Matematika Anak Kelas VI Satdik SD Negeri 1 Tulamben Semester I Tahun Pelajaran 2019/2020 Siklus I

Kekurangan-kekurangan/kelemahan-kelemahan yang ada dari pelaksanaan tindakan siklus I adalah: 1) Agak sulit diupayakan akibat kebiasaan peserta didik lebih senang santai. Lingkungan peserta didik yang kurang mendukung untuk merekaaktif belajar. 2) Siswa belum aktif bertanya. 3) Kemauan siswa untuk menyelesaikan tugas-tugas yang disuruh masih rendah. 4) Peserta didik belum sepenuhnya berniat untuk meningkatkan kemampuan belajar mereka. 5) Diperlukan dukungan orang tua agar ikut mengarahkan an anak-anaknya untuk lebih giat belajar. Sedangkan kelebihan yang ditemukan pada pelaksanaan tindakan siklus I adalah: 1)Proses belajar mengajar dapat dilakukan dengan perencanaan yang sudah matang.

\section{Siklus II}

Dengan melihat semua hasil yang didapat pada siklus I, maka untuk perencanaan pelaksanaan penelitian di siklus II ini ada beberapa hal yang perlu dilakukan yaitu: 1) Peneliti merencanakan kembali jadwal untuk melakukan pembelajaran di kelas dengan melihat jadwal penelitian. Hasil dari refleksi siklus I merupakan dasar dari pembuatan perencanaan di siklus ini. 2) Menyusun rencana pelaksanaan pembelajaran yang baik serta membuat instrumen pengumpulan data. Instrumen pengumpulan data yang dibuat seperti instrumen tes prestasi belajar. 3) Bersama guru merancang skenario penerapan pembelajaran dengan melihat kekurangan-kekurangan yang ada pada siklus I dengan mengidentifikasi hal-hal yang bisa dilakukan untuk peningkatan pembelajaran. Untuk hal ini, semua catatan tentang kekurangan yang ada di siklus I yang merupakan hasil refleksi disampaikan pada guru untuk dipelajari. Memberi tahu guru apa-apa yang perlu dilaksanakan, apa saja yang siswa mesti kerjakan, cara penerapan model pembelajaran yang benar sesuai dengan yang diharapkan.

Uraian tentang pelaksanaan tindakan pada siklus II ini disampaikan sebagai berikut: 1) Pada hari yang sudah ditentukan sesuai jadwal, peneliti memulai tahap pelaksanaan tindakan dengan membawa semua persiapan yang sudah dibuat. Problem Solving mulai diupayakan dalam pembelajaran, pada kali yang kedua ini peneliti mengajak kepala sekolah untuk ke kelas dan ikut melakukan pengamatan. Hal ini dilakukan dengan harapan peneliti akan lebih bersemangat untuk dapat melaksanakan pembelajaran lebih serius. Dengan kepala sekolah ikut mengamati berarti ada orang lain yang mesti dilihat oleh siswa yang akan menimbulkan keseriusan mereka yang lebih dari biasanya. Peneliti membawa instrumen pengamatan observasi keaktifan belajar dan instrumen tes prestasi belajar. Setelah masuk kelas bersama guru yang akan mengamati proses pembelajaran memulai aktivitas pembelajaran sambil mempersilahkan kepala sekolah dan guru yang mengamati duduk di bangku paling belakang yang sudah disediakan. Setelah pelaksanaan pembelajaran berjalan, tiba-tiba kepala sekolah dicari oleh pegawainya karena ada urusan kantor, sehingga pengamatan melaksanakan pembelajaran hanya dilanjutkan oleh guru yang penulis minta untuk mengobservasi proses selanjutnya. Di belakang, guru yang mengamati proses pembelajaran sangat aktif menulis hal-hal yang terjadi di kelas untuk memberi penilaian terhadap kemampuan dan profesionalisme guru sedangkan di depan kelas peneliti sibuk dengan pelaksanaan pembelajaran yang dilaksanakan di kelas. Pada pembelajaran inti peneliti melaksanakan explorasi, 
elaborasi dan konfirmasi dengan membagi siswa menjadi kelompok-kelompok kecil untuk siap menerima pembelajaran, dan terakhir peneliti melaksanakan penutupan pembelajaran. Untuk pelaksanaan explorasi, elaborasi dan konfirmasi bagian-bagiannya cukup banyak dan penulis tidak paparkan panjang lebar karena kegiatan yang mesti dilakukan seperti diskusi, presentasi dan lain-lain sudah bisa dibaca pada instrumen rencana pelaksanaan pembelajaran.

Hasil pengamatan melalui pemberian tes prestasi belajar disimpulkan pada Tabel berikut:

Tabel 2. Prestasi Belajar Matematika Siswa Kelas VI Semester I Tahun Pelajaran 2019/2020 Siklus II

\begin{tabular}{cc}
\hline Kreteria penilain & NILAI \\
\hline Jumlah & 2690 \\
\hline Rata-rata & 72,70 \\
\hline Nilai Tertinggi & 90 \\
\hline Nilai Terendah & 60 \\
\hline Modus & 60 \\
\hline Median & 70 \\
\hline KKM & 60 \\
\hline Jumlah Siswa yang Perlu Diberi Pengayaan & $37(100 \%)$ \\
\hline Jumlah Siswa yang Mesti Diremidi & $0(0 \%)$ \\
\hline
\end{tabular}

Dari 37 peserta didik yang diteliti ada pada siklus II ini tenyata semuanya bisa melebihi indikator yang telah ditentukan. Terhitung $100 \%$ siswa telah melebihi indikator yang dituntut. Deskripsi yang dapat disimpulkan adanya peningkatan hasil dari siklus II yaitu 14 orang siswa bisa mencapai KKM yang ditentukan, 23 orang siswa bisa melampui KKM. Pada siklus II semua siswa telah tuntas. dengan kata lain ketuntasannya 100\%. Lebih rinci akan digambarkan pada histrogram dibawah ini.

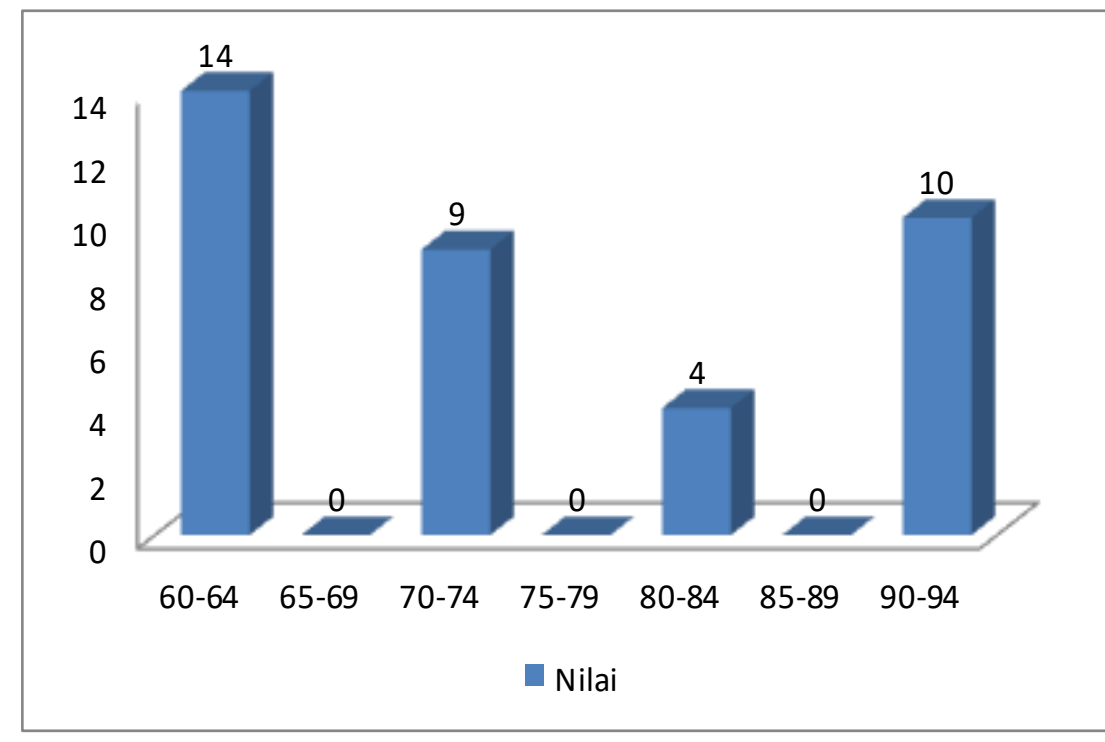

Gambar 3. Histogram Prestasi Belajar Matematika Siswa Kelas VI Satdik SD Negeri 1 TulambenSemester I Tahun Pelajaran 2019/2020 Siklus II

Kekurangan-kekurangan/kelemahan-kelemahan yang ada dari pelaksanaan tindakan siklus II adalah:Terlihat jelas keaktipan dari pada siswa,namun dari keaktifan tersebut ternyata membuat kelas sedikit gaduh dan sedikit ribut. Sedangkan kelebihan yang ditemukan pada pelaksanaan tindakan siklus II adalah: 1. Siswa sudah terlihat lebih aktif tidak apatis lebih berminat dalam mengikuti proses belajar mengajar. 2. Kebiasaan peserta didi aktif bekerja aktif mampu ditingkatkan srcara dini. 3. Model ini mampu meningkatkan minat siswa dalam belajar, semangat mereka memenunggu perintah meningkatkan antusiasme dalam pembelajaran. 4. Siswa mampu beradaptasi dengan situasi belajar 
mengajar yang berbeda dari sebelumnya, biasanya siswa hanya mendengarkan penjelasan guru, namun dengan model ini siswa sudah berani bertanya dan adu argumentasi.

\section{Pembahasan}

\section{Siklus I}

Hal-hal yang perlu diperhatikan dalam pembahasan data kualitatif adalah: kelemahan-kelemahan yang ada, kelebihan-kelebihan, perubahan-perubahan, kemajuan-kemajuan, efketivitas waktu, keaktifan yang dilakukan, konstruksi, kontribusi, diskripsi fakta, pengecekan validitas internal dan validitas eksternal, identifikasi masalah, faktor-faktor yang berpengaruh, cara-cara untuk memecahkan masalah, pertimbangan-pertimbangan, perbandingan-perbandingan, komentar-komentar, tanggapan-tanggapan, tambahan pengalaman, summary, pendapat-pendapat, gambaran-gambaran, interpretasi/penafsiranpenafsiran, makna di belakang perbuatan, trianggulasi, hubungan antaraspek, klasifikasi, standar-standar penetapan nilai, alasan-alasan penggunan teknik tertentu, alasan penggunaan langkah-langkah tertentu, penggolongan-penggolongan, penggabungan-penggabungan, tabulasi, pemakaian, kriteria-kriteria, katagorisasi, pengertian-pengertian, hubungan antar kategori.

Hasil tes prestasi belajar yang merupakan tes pilihan ganda memforsir siswa untuk betul-betul dapat memahami apa yang sudah dipelajari. Nilai rata-rata siswa di siklus I sebesar 64,595 menunjukkan bahwa siswa setelah menguasai materi yang diajarkan walaupun belum begitu sempurna. Hasil ini menunjukkan peningkatan kemampuan siswa menguasai mata pelajaran matematika. Apabila dibandingkan dengan nilai awal siswa sesuai data yang sudah disampaikan dalam analisis sebelumnya yang hanya mencapai 55,946 .

Hasil tes prestasi belajar di siklus I telah menemukan efek utama bahwa penggunaan metode tertentu akan berpengaruh terhadap prestasi belajar siswa yang dalam hal ini adalah model pembelajaran Problem Solving. Hal ini sesuai dengan hasil meta analisis metode pembelajaran yang dilakukan oleh Soedomo (1989/1990) yang menyatakan bahwa metode pembelajaran yang diterapkan oleh seorang guru berpengaruh terhadap prestasi belajarnya.

Seperti telah diketahui bersama bahwasannya mata pelajaran matematika menitikberatkan pembelajaran pada aspek kognitif, afektif, dan pskimotor sebagai pedoman prilaku kehidupan sehari-hari siswa. Untuk penyelesaian kesulitan yang ada maka penggunaan metode ini dapat membantu siswa untuk berkreasi, bertindak aktif, bertukar pikiran, mengeluarkan pendapat, bertanya, berdiskusi, berargumentasi, bertukar informasi dan memecahkan masalah yang ada bersama dengan anggota kelompok diskusinya. Hal inilah yang membuat siswa berpikir lebih tajam, lebih kreatif dan kritis sehingga mampu untuk memecahkan masalah-masalah yang kompleks dan efek selanjutnya adalah para siswa akan dapat memahami dan meresapi mata pelajaran matematika lebih jauh.

Kendala yang masih tersisa yang perlu dibahas adalah prestasi belajar yang dicapai pada siklus I ini belum memenuhi harapan sesuai dengan tuntutan KKM mata pelajaran matematika di sekolah ini yaitu 60. Oleh karenanya upaya perbaikan lebih lanjut masih perlu diupayakan sehingga perlu dilakukan perencanaan yang lebih matang untuk siklus selanjutnya.

\section{Siklus II}

Hasil yang diperoleh dari tes prestasi belajar di siklus II menunjukkan bahwa kemampuan siswa dalam mengikuti pelajaran sudah cukup baik. Ini terbukti dari rata-rata nilai siswa mencapai 72,703. Hasil ini menunjukkan bahwa model pembelajaran Problem Solving telah berhasil meningkatkan kemampuan siswa menempa ilmu sesuai harapan. Problem Solving merupakan model yang cocok bagi siswa apabila guru menginginkan mereka memiliki kemampuan berkreasi, berargumentasi, mengeluarkan pendapat secara lugas, bertukar pikiran, berargumentasi, mengingat penggunaan metode ini adalah untuk memupuk kemampuan berbicara dihadapan orang banyak.

Hasil penelitian ini ternyata telah memberi efek utama bahwa model yang diterapkan dalam proses pembelajaran berpengaruh secara signifikan terhadap prestasi belajar siswa. Temuan ini membuktikan bahwa guru sudah tepat memilih metode dalam melaksanakan proses pembelajaran karena pemilihan metode merupakan hal yang tidak boleh dikesampingkan. Hal ini sejalan pula dengan temuan-temuan peneliti lain seperti yang dilakukan oleh Inten (2004) dan Puger (2004) yang pada dasarnya menyatakan bahwa metode pembelajaran yang diterapkan berpengaruh terhadap prestasi belajar siswa.

Mata pelajaran matematika menitikberatkan kajiannya pada aspek kognitif, afektif dan pskimotor sebagai pedoman atas kemampuan siswa baik pikiran, prilaku maupun keterampilan yang dimiliki. Untuk semua bantuan terhadap hal ini, model pembelajaran Problem Solving menempati tempat yang penting karena dapat meningkatkan prestasi belajar siswa secara maksimal. Walaupun penelitian ini sudah bisa dikatakan berhasil, namun pada saat-saat peneliti mengajar di kelas cara selanjutnya, cara ini akan terus dicobakan termasuk di kelas-kelas lain yang peneliti ajar. 
Setelah dibandingkan nilai awal, nilai siklus I dan nilai siklus II, terjadi kenaikan yang signifikan, yaitu dari rata-rata nilai awal adalah 55,946 naik di siklus I menjadi 64,595 dan di siklus II naik menjadi 72,703. Sedangakn ketuntasan belajar siswa juga mengalami peningkatan dari awal siklus 37,84\% meningkat menjadi $64,86 \%$ pada siklus I. Dan pada siklus II menjadi $100 \%$. Kenaikan ini tidak bisa dipandang sebelah mata karena kenaikan nilai ini adalah dari upaya-upaya yang maksimal yang dilaksanakan peneliti demi peningkatan mutu pendidikan dan kemajuan pendidikan khususnya di Satdik SD Negeri 1 Tulamben.

\section{Simpulan Dan Saran}

Bertitik tolak dari pemicu rendahnya aktivitas belajar dan prestasi belajar ada pada faktor-faktor seperti metode yang digunakan guru, sehingga penggunaan atau penggantian metode konvensional menjadi metode-metode yang sifatnya konstruktivis sangat diperlukan, akibatnya peneliti mencoba model pembelajaran Problem Solving dalam upaya untuk dapat memecahkan permasalahan yang ada. Penerapan model pembelajaran Problem Solving terbukti dapat peningkatan prestasi belajar siswa yang ditandai dengan kenaikan prestasi belajar siswa. Dari data awal ada 23 siswa mendapat nilai dibawah KKM dan pada siklus I menurun menjadi 13 siswa dan siklus II 14 siswa mendapat nilai sama dengan KKM dan selebihnya diatas KKM. Dari rata-rata awal 55,946 naik menjadi 64,595 pada siklus I dan pada siklus II naik menjadi 72,703. Dari data awal siswa yang tuntas hanya 37,84\% atau 14 orang sedangkan pada siklus I menjadi lebih banyak yaitu $64,86 \%$ atau 24 siswa dan pada siklus II menjadi 37 siswa atau ketuntasannya $100 \%$.

Berdasarkan temuan yang sudah disimpulan dari hasil penelitian, dalam upaya mencapai tujuan pembelajaran dalam bidang studi matematika, dapat disampaikan saran-saran sebagai berikut: 1) Dalam melaksanakan proses pembelajaran pada mata pelajaran matematika, penggunaan model pembelajaran Problem Solving semestinya menjadi pilihan dari beberapa model yang ada mengingat model ini telah terbukti dapat meningkatkan kerjasama, berkreasi, bertindak aktif, bertukar informasi, mengeluarkan pendapat, bertanya, berdiskusi, dan berargumentasi. 2) Walaupun penelitian ini sudah dapat membuktikan efek utama dari model Problem Solving dalam meningkatkan prestasi belajar, sudah pasti dalam penelitian ini masih ada hal-hal yang belum sempurna dilakukan, oleh karenanya kepada peneliti lain yang berminat meneliti topik yang sama untuk meneliti bagian-bagian yang tidak sempat diteliti. 3) Selanjutnya untuk adanya penguatan-penguatan, diharapkan bagi peneliti lain untuk melakukan penelitian lanjutan guna verifikasi data hasil penelitian.

\section{Daftar Rujukan}

Arikunto, Suharsimi; Suhardjono; Supardi. 2007. Penelitian Tindakan Kelas. Jakarta: PT Bumi Aksara.

Badan Standar Nasional Pendidikan. 2007. Peraturan Menteri Pendidikan Nasional Republik Indonesia Nomor 41 Tahun 2007. Jakarta: BSNP.

Dahar, Ratna Wilis. 1989. Teori-Teori Belajar. Jakarta: Penerbit Erlangga.

Depdiknas. 2009. Co-Op Co-Op . Jakarta: Dirjen Pendidikan Dasar dan Menengah.

Dharma Kesuma dkk. 2012. Pendidikan Karakter Kajian Teori dan Praktik di Sekolah. Bandung: PT Remaja Rosdakarya.

Dimyati \& Mudjiono. 2009. Belajar dan Pembelajaran. Jakarta: Rineka Cipta.

Djamarah, Syaful Bahri. 2012. Prestasi Belajar dan Kompetensi Guru. Surabaya: Usaha Nasional.

Erman Suherman. (2003). Strategi Pengajaran Matematika Kontemporer. Bandung: JICA

Gulo, W. (2002). Strategi Belajar Mengajar. Jakarta : PT. Grasindo

Herman Hudojo. (2003). Pengembangan Kurikulum dan Pembelajaran Matematika. Malang: Universitas Negeri Malang

Heruman. 2012. Model Pembelajaran Matematika di Sekolah Dasar. Bandung: Remaja Rosdakarya. 
Inten, I Gede. 2004. Pengaruh Model Pembelajaran dan Pengetahuan Awal Siswa Terhadap Prestasi Belajar PKN dan Sejarah Pada Siswa Kelas II SMU Laboratorium IKIP Negeri Singaraja. Tesis. Singaraja. Program Pascasarjana IKIP Negeri Singaraja.

Johnson, Elaine B. (2002). Contextual Teaching and Learning: What it is and why it's her to stay. Corwin Press, Inc: California.

Modern Educators and Lexicographers. 1993. Webster's New American Detionary. New York: 140 Broadway, Books, Inc.

Nana Sudjana. 2010. Cara belajar Siswa Aktif dalam Proses Belajar Megajar. Bandung: Sinar Baru Algensindo.

Nur, Mohamad et al. 2007. Pengembangan Model Pembelajaran IPA Berorientasi Masalah Kontekstrual untuk Meningkatkan Daya Nalar Mahasiswa dalam Rangka Menyongsong Masyarakat IPTEK pada Pembangunan Jangka Panjang Tahap Kedua. Makalah. Disampaikan pada Seminar Hasil-hasil Penelitian Unggulan. IKIP Negeri Surabaya.

Puger, I Gusti Ngurah. 2004. Pengaruh Model Pembelajaran dan Kemampuan Berpikir Silogisme Terhadap Prestasi Belajar Biologi Pada Siswa Kelas III SMP Negeri Seririt (Experimen Pada Pokok Bahasan Reproduksi Generatif Tumbuhan Angiospermae). Tesis. Singaraja: IKIP Negeri Singaraja.

Peraturan Menteri Pendidikan Nasional No. 41 Tahun 2007 Tanggal 23 November 2007. Jakarta: Depdiknas.

Purwanto, Ngalim. 2000. Psikologi Pendidikan. Bandung: Rosdakarya.

Sardiman, A.M. 1988. Interaksi dan Motivasi Belajar-Mengajar Pedoman bagi Guru dan Calon Guru. Jakarta: Rajawali Pers.

Sindoro, Alexander. 2003. Kebugaran Otak dalam Kehidupan Sehari-hari. Terjemahan dari Buku Brain Fitness@work Karangan Judith Jewell.

Slamet. 2003. Belajar dan Faktor-Faktor yang Mempengaruhinya. Jakarta: Rineka Cipta.

Slameto. 2013. Belajar dan Faktor-Faktor yang Mempengaruhinnya. Jakarta: PT Rineka Cipta

Sudjana,Nana. 2010. Cara belajar Siswa Aktif dalam Proses Belajar Megajar. Bandung: Sinar Baru Algensindo.

Tim Prima Pena. Kamus Besar Bahasa Indonesia. Gramedia Press.

Wardani Dyah Retno Kusuma. 2011. Pengaruh Metode Pembelajaran Proglem Solving ddan Group Investigation terhadap Keterampilan Berpikir Tingkat Tinggi dengan Mempertimbangkan Kreativitas pada Siswa Kelas VIII SMP Negeri 3 Denpasar Tahun Ajaran 2010/2011. Tesis. Universitas Pendidikan Ganesha Program Pascasarjana Singaraja.

Wardani, I. G. A. K Siti Julaeha. Modul IDIK 4307. Pemantapan Kemampuan Mengajar. Jakarta: Universitas Terbuka. 